\title{
The Effectiveness of the Business Incubator and Entrepreneurial Education in Interest to Start a Business in Vocational School Students Majoring in Marketing
}

\author{
R Sulistyowati ${ }^{1}$ \\ 1Departement of Economics Educations, Faculty of Economic and Business, Universitas Negeri Surabaya, Surabaya \\ 60231, Indonesia
}

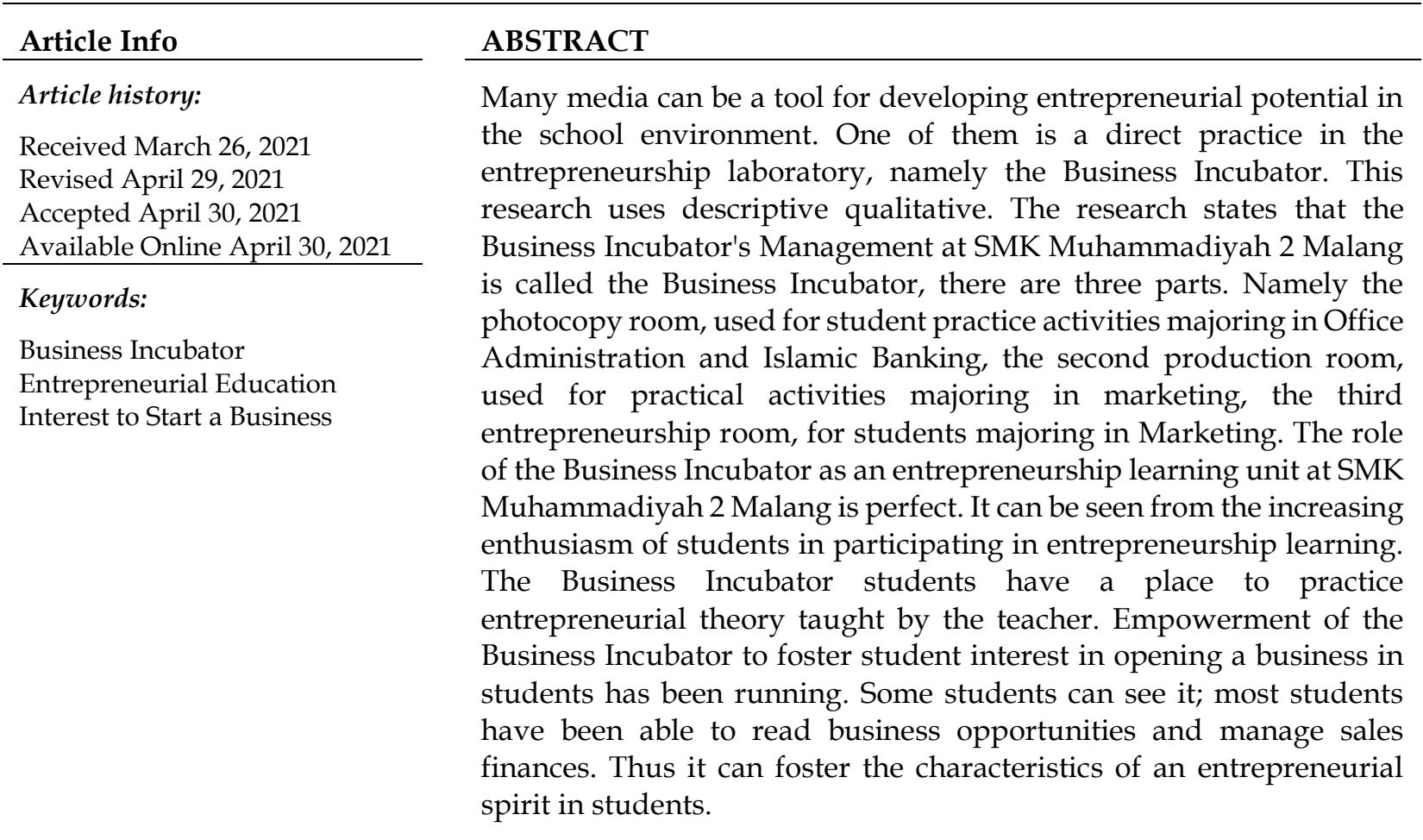

\section{INTRODUCTION}

Vocational education is a place to prepare students to become productive humans, able to work independently, filling existing job vacancies according to the competencies in the expertise program they choose (Moslem et al., 2019). To be independent and productive, Vocational High School (SMK) students need to change their way of thinking by not becoming workers, but becoming someone who opens new jobs for others, because currently, competition in the business world is very tight along with the number of available jobs. not proportional to the number of workers (Basri et al., 2019; Perwita, 2017).

The cause of the increase in unemployment cannot be separated from the education system which only emphasizes theory rather than practice (Nastiti \& 'Abdu, 2020; Rifai \& Sucihatiningsih, 2016). Therefore, to improve prospective SMK graduates' identity who have high-quality human resources, skills and can be competitive, for example, through education with entrepreneurship lessons (Usman \& Raharjo, 2012).

Efforts to reduce unemployment, at least there must be a change in the community's mindset, especially for SMK graduates from looking for work to creating jobs (Prihastiwi et al., 2018). Therefore, SMK graduates are not only focused on preparing to become a workforce in the 
The effectiveness of the Business Incubator and Entrepreneurial Education in Interest to Start a Business in Vocational School Students Majoring in Marketing

https://doi.org/10.46627/silet.v2i1.61

business world but also on the willingness to become entrepreneurs (Basri et al., 2019). Courage to do business is the main asset a person must have to enter the world of work. The entrepreneurial interest of SMK graduates is still shallow (Ulgari et al., 2020). Because the practice of doing entrepreneurial activities is not easy, excessive fear of failure and loss often haunts one's soul when starting a business.

To achieve educational goals, especially at the vocational level, has developed and implemented entrepreneurship lessons in the national curriculum for the Vocational Intermediate Level. This lesson is given to SMK following their respective skill competencies with theory and practice (Rami \& Supardi, 2019). This combination is expected so that students will have the knowledge and skills after graduating. Because the entrepreneurship education given since SMK will foster an entrepreneurial spirit after graduation. Entrepreneurship education provides a theoretical basis for the concept of entrepreneurship and forms attitudes, behaviours, and a person's mindset in entrepreneurship. Capital investment to prepare students to start new businesses through the experience, skills and knowledge essential to entrepreneurship (Wibowo, 2017).

Many media can be a tool for developing entrepreneurial potential in the school environment (Amin et al., 2020). They are first forming a student activity unit to train entrepreneurial competence by making various types of handicrafts from students. Second, making a juju canteen is intended to train students' honesty because honesty is one of the characteristics of someone who has an entrepreneurial character. Third, student entrepreneurship training with hands-on practice in the entrepreneurial laboratory, namely the Business Incubator.

The Business Incubator is a place to conduct trading business by involving education elements by relevant expertise competencies and can be implemented in a combination system with other skill systems (Lutfiani et al., 2020). The role of the Business Incubator, namely a training and education place for students that functions as a school production unit and as an entrepreneurial laboratory for students to carry out entrepreneurial practices, calculations or bookkeeping (Budiyanto et al., 2017). The existence of this practice is expected to motivate students in fostering student interest in entrepreneurship.

Based on the Republic of Indonesia Number 19 of 2005 concerning National Education Standards in Chapter VII Article 42 Paragraph 2 states that.

Each academic unit is required to have infrastructure which includes land, classrooms, academic unit leadership rooms, teaching rooms, administration rooms, library rooms, laboratory rooms, workshops, production unit rooms, canteen rooms, power and service installations, sports venues, a place of worship, a place to play, a place to create, and other spaces/places needed to support an orderly and sustainable learning process.

Apart from that, as a place for entrepreneurial practice and training, the Business Incubator can help students provide training on how to trade, market an item, and open another business. This is done in opening a business by selling items in the Business Incubator to be sold in the business environment. It was intended to train students' independence and courage in communicating with customers and at the same time learning about marketing (Usman \& Raharjo, 2012).

This was reinforced by the existence of relevant previous research by amin et al. (2020), komara \& bagus setiawan (2020), and lutfiani et al. (2020) Concluded that the current Business Incubator Management Model is not yet optimal, the Business Incubator Management Model as a result of the development consists of model components, model content and objectives. The model component includes a management function consisting of planning, organizing, implementing, supervising and managing the Business Incubator, covering aspects of production, marketing, finance, and human resources. The stages of implementing the Business Incubator consist of socialization, honest business, Business application activities. The Business Incubator management model can be implemented effectively and efficiently. 
The effectiveness of the Business Incubator and Entrepreneurial Education in Interest to Start a Business in Vocational School Students Majoring in Marketing

https://doi.org/10.46627/silet.v2i1.61

Based on the background described above, this research's focus is as follows: (1) Management of Business Incubators at SMK. (2) The effectiveness of the role of the Business Incubator as an entrepreneurial learning unit in SMK. (3) Empowerment of Business Incubators as a means of fostering student interest in opening businesses.

\section{RESEARCH METHOD}

This research uses a qualitative approach with descriptive research type. This research took place at SMK Muhammadiyah 2 Malang, located on Jalan Baiduri Sepah No.27, Tlogomas, Kec. Lowokwaru, Malang City. The data collection technique is done by observing, interviewing, and documenting. To test the data collected's validity, the researcher will do: first triangulation techniques between data sources, between data collection techniques, and between data collectors. Second, check the information's correctness to the informants the researcher in the research report has written. Third, I will discuss with colleagues in the department where the researcher teaches, including corrections under the supervisor - fourth, negative case analysis, namely cases that are not by the study results. Fifth, extend the research time. The research stages include pre-field training, selecting research locations, determining the object's boundaries, understudy, taking care of permits, selecting informants.

Table 1. Informant Research

\begin{tabular}{clll} 
No. & \multicolumn{1}{c}{ Informant } & \multicolumn{1}{c}{ Excavated information } & Description as \\
\hline 1. & $\begin{array}{l}\text { Entrepreneurship } \\
\text { teacher }\end{array}$ & $\begin{array}{l}\text { To explore information about entrepreneurial } \\
\text { learning practices carried out at the Business } \\
\text { Incubator }\end{array}$ & $\begin{array}{l}\text { Major } \\
\text { Informants }\end{array}$ \\
\hline 2. & $\begin{array}{l}\text { Management teacher } \\
\text { and chairman of the } \\
\text { Business Incubator }\end{array}$ & $\begin{array}{l}\text { To dig up information about the management } \\
\text { activities of the Muhammadiyah 2 SMK } \\
\text { Muhammadiyah 2 Business Incubator }\end{array}$ & $\begin{array}{l}\text { Major } \\
\text { Informants }\end{array}$ \\
\hline 3. & $\begin{array}{l}\text { Student managing the } \\
\text { Business Incubator }\end{array}$ & $\begin{array}{l}\text { To find out information on the effectiveness of } \\
\text { entrepreneurship learning in the Business }\end{array}$ & $\begin{array}{l}\text { Additional } \\
\text { informants }\end{array}$ \\
& & $\begin{array}{l}\text { Incubator in fostering student interest in } \\
\text { entrepreneurship }\end{array}$ & \\
\hline 4. & $\begin{array}{l}\text { Waka chart of facilities } \\
\text { and infrastructure }\end{array}$ & $\begin{array}{l}\text { To find out general information about the need } \\
\text { for facilities and infrastructure in the Business } \\
\text { Incubator at SMK Muhammadiyah 2 Malang }\end{array}$ & $\begin{array}{l}\text { Major } \\
\text { Informants }\end{array}$ \\
\hline
\end{tabular}

(Source: Researcher, 2021)

\section{RESULTS AND DISCUSSION}

\section{Management of Business Incubators at SMK Muhammadiyah 2 Malang}

So that all SMK Muhammadiyah 2 Malang Business Incubator activities are controlled, a Business Incubator management is formed. There are many functions of the organizational structure of the Business Incubator SMK Muhammadiyah 2 Malang. Descaprio (2013) states that there are four functions of Laboratory organizational structure, namely facilitating practice and research planning, facilitating management of research and practice activities in the laboratory, facilitating reporting and accountability for all activities in the laboratory so that they are quickly evaluated, making it easier to supervise all activities in the laboratory.

Management of the Business Incubator is, of course, not solely for commercial purposes. In general, the management of the SMK Muhammadiyah 2 Malang Business Incubator is based on the basics of laboratory management according to Descaprio (2013) , which states, "Business incubators are managed and designed to improve, grow and develop the skills of their users in various activities." For example, if a Business Incubator is in the room. In the school's scope, the administrators must be able to improve students 'entrepreneurial learning practices and foster 
students' interest in becoming entrepreneurs. The Business Incubator must be managed and designed to train the ability to compile and analyze the practice results, which are then continued to interpret the results of the practice. Therefore, the Business Incubator becomes the basis for the psychomotor development of students. Business Incubators are managed and designed to train skills in designing practical activities and implementing them. In the practice of entrepreneurship learning in the Business Incubator, students are taught to carry out product pentatonic, recap sales, excellent service, such as entrepreneurship learning theory that has been taught. The Business Incubator must be managed and designed flexibly and not pressure on those involved in it. This means that anyone can help manage the management of the Business Incubator at SMK Muhammadiyah 2 Malang.

In general, the management of the Business Incubator at SMK Muhammadiyah 2 Malang is based on the laboratory management stated by Susanto (2017) as follows: (1) The Business Incubator must be managed and designed to improve, grow, and develop its users' skills in a variety of activities. For example, suppose a Business Incubator is in the scope of the School. In that case, the manager must be able to improve students 'entrepreneurial learning practices, and foster students' interest in becoming entrepreneurs, (2) Business Incubators must be managed and designed to be able to train the ability to compile and analyze practical results which are then continued to interpret the results of the practice. Therefore, the Business Incubator becomes the basis for students' psychomotor development, (3) The Business Incubator must be managed and designed to train the ability to communicate the results of practical activities. This means that in the practice of entrepreneurship learning in the Business Incubator, students are taught to communicate with customers, (4) Business Incubators must be managed and designed to train skills in designing practical activities and implementing them. This means that in the practice of entrepreneurship learning in the Business Incubator students are taught to carry out product promotion, recap sales, excellent service, such as entrepreneurship learning theory that has been taught, and (5) Business Incubators must be managed and designed flexibly and not pressure anyone involved in therein. This means that anyone can help manage the management of the Business Incubator at SMK Muhammadiyah 2 Malang.

In the Business Incubator organizational structure, there are several positions and responsibilities for each task. Descaprio (2013) several positions must exist in every Business Incubator organizational structure, including the technical person in charge, the head of the Business Incubator manager, the coordinator of each Business Incubator field, and the Teacher who manages the Business Incubator. The board of directors' management and the Business Incubator/Marketing Officer's duties and responsibilities at SMK Muhammadiyah 2 Malang are as follows. 


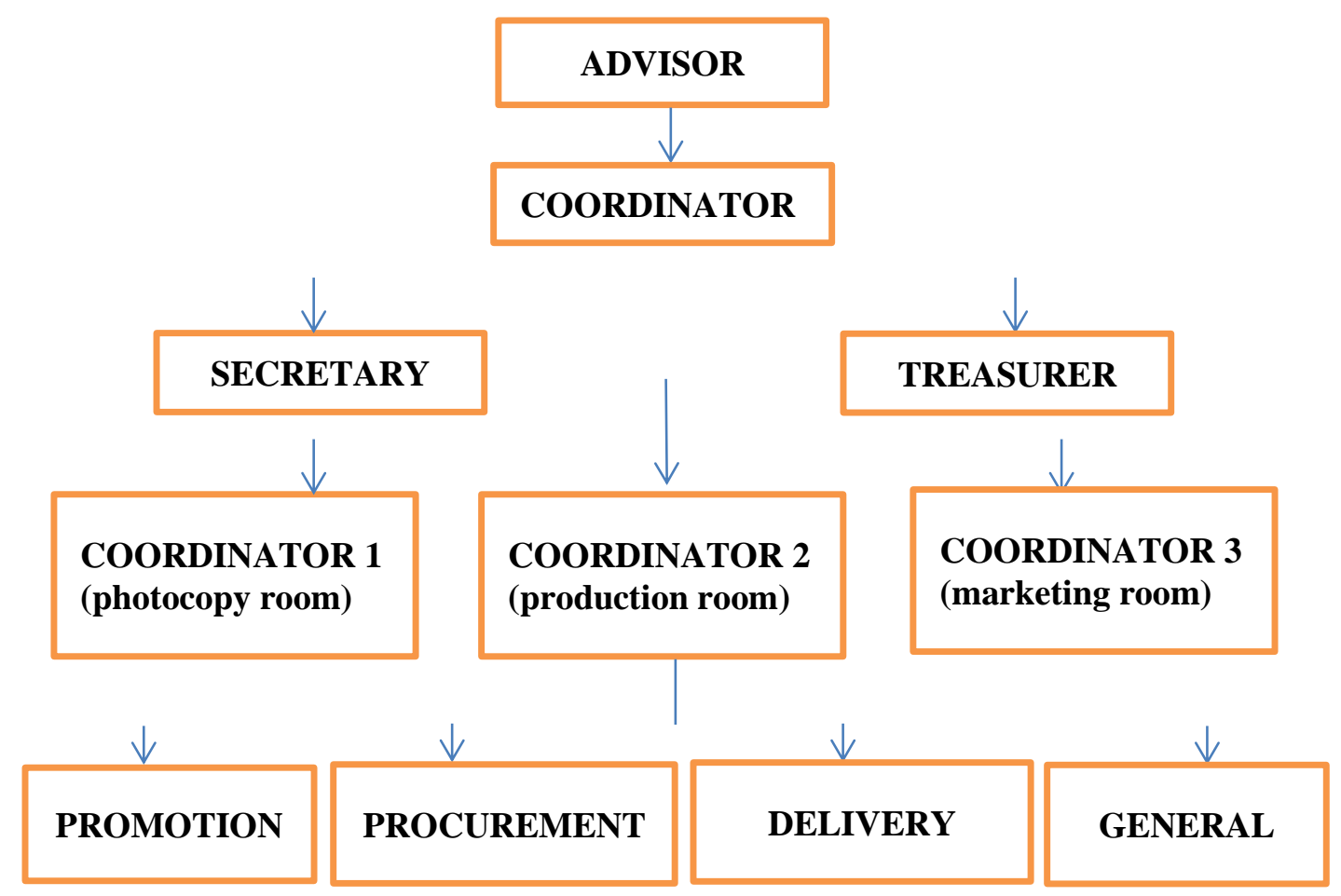

Figure 1. Organizational Structure of the Business Incubator at SMK Muhammadiyah 2 Malang (Source: Business Incubator SMK Muhammadiyah 2 Malang)

Advisor
General Coordinator
Coordinator I
Coordinator II
Coordinator III
Secretary
Treasurer
Promotion
Procurement
Delivery
General

: Nur Cholis, S.Pd

: Elok Nurani, S.Pd

: Dra. Yayuk Pujiastuti

: Elok Nurani, S.Pd

: Misriyah, S.Pd

: Elok Nurani, S.Pd

: Dra. Yunanik

: Seluruh Wali Kelas

: Misriyah, S.Pd \& Dra. Yunanik

: Elok Nurani, S.Pd \& Dra. Indah Sulistyowati

: Enny Dian Handayani, S.Pd \& Mila Irawati, S.Pd

So far, the management of the Business Incubator at SMK Muhammadiyah 2 Malang has been running correctly. In the production room and the shop, the marketing room is functioning on a semifinal basis. However, it is miserable that the Photocopy room Business Incubator does not function as it should be used as an additional teacher room. The factor that causes this to happen is that some of the Photocopy room, Business Incubator tools cannot be used.

Emha (2006) many other factors have caused the shift in the function of the Laboratory/Business Incubator as a place to observe, find, and solve a problem, including, Lack of ability to manage School Laboratories, both from school leaders and teachers, Lack of understanding of the meaning and function of school laboratories and their implications for development. And improvement of the learning system. The procurement of facilities and infrastructure has not been evenly distributed, making learning practice difficult. One vital learning resource is the learning practice facilities and infrastructure that can help clarify concepts or understand and train students to achieve specific skills. The learning process using teaching 
The effectiveness of the Business Incubator and Entrepreneurial Education in Interest to Start a Business in Vocational School Students Majoring in Marketing

https://doi.org/10.46627/silet.v2i1.61

aids/practices makes students have clear responses to the stimuli provided to leave a perfect observation impression on each student.

Based on the Government Regulation of the Republic of Indonesia Number 19 of 2005 concerning National Education Standards in Chapter VII Article 43 Paragraph 1 states that "Standards for the diversity of types of natural science laboratory equipment (IPA), language laboratories, computer laboratories, and other learning equipment in academic units are stated in the list, which contains the minimum type of equipment that must be available." The purpose of establishing the Entrepreneurship Laboratory or Business Incubator is to make it easier for students to understand the teacher's entrepreneurial learning theory, develop students' abilities, and foster an entrepreneurial spirit in students. The objectives of student activities in the Laboratory include: (1) Able to interpret experimental results to obtain findings and be able to solve problems, (2) Be thorough in practicing observations and be careful in recording observational practices, (3) Be able to plan and carry out experiments about what is being learned or researched in the Laboratory, (4) Skilled in carrying out practices using Laboratory equipment, and (5) Growing a positive attitude in carrying out practices in the Laboratory (Susanto, 2017).

The management of the Business Incubator at SMK Muhammadiyah 2 Malang is running well. This can be proven by an organizational structure's existence, running the management of the Business Incubator at SMK Muhammadiyah 2 Malang by their duties and responsibilities. However, it still lacks maintenance regarding the facilities and infrastructure in the SMK Muhammadiyah 2 Malang Business Incubator. This can be seen in the Photocopy room Business Incubator, which is currently not being used properly because the photocopy room tools cannot be used. Then the Business Incubator in the marketing room shop also lacks tools in the form of a cash register, making it difficult for students to practice entrepreneurship learning (Descaprio ,2013)

\section{Effectiveness of the Role of a Business Incubator as an Entrepreneurship Learning Unit}

Learning is an activity or process to gain knowledge, improve skills, improve attitudes and strengthen personality. Learning is believed to be able to develop various potentials that humans have. With the learning, it is hoped that it can increase the knowledge, attitudes, and skills that are owned. Learning is a conscious effort that aims to change a person's behavior. These learning activities need to be designed, arranged, monitored in such a way and evaluated to achieve predetermined goals (Suryono \& Hariyanto, 2012).

Entrepreneurship learning means a pattern that is used as a basic guideline in the form of global policies through stages that are directed to carry out ideal interactions between managers of educational institutions, educators, and student trainees, which are planned and organized in an education management mechanism and contain design and development factors for learning activities entrepreneurship (Sabatari \& Hariyanto, 2015). The objectives of holding entrepreneurship learning are (1) building entrepreneurial character; (2) preparing business practice-based entrepreneurship learning services; (3) preparing industrial teaching pilot in SMK; (4) preparing junior high school graduates to become entrepreneurs.

In order to achieve this goal, the Business Incubator SMK Muhammadiyah 2 Malang makes programs that involve active students in the management of the program, starting from activities in production, helping to produce original product drinks from SMK Muhammadiyah 2 Malang turmeric Asem, helping packing orders, making products itself for sale. In addition to the production site, students are also actively involved in managing the shop's Business Incubator. In the Business Incubator, students are given picket schedules to be on guard, student activities in the store's Business Incubator, starting from cleaning the room, arranging products, serving customers, recording bookkeeping, etc. by being actively involved in the management of the Business Incubator, it will increase understanding of learning entrepreneurship.

Learning entrepreneurship through practice in the Business Incubator is very effective and positively affects students' entrepreneurial competence. This is by the relevant previous research 
The effectiveness of the Business Incubator and Entrepreneurial Education in Interest to Start a Business in Vocational School Students Majoring in Marketing

https://doi.org/10.46627/silet.v2i1.61

by Lutfiani et al. (2020) who found that business incubators play an essential role in encouraging student creativity and innovation in entrepreneurship. The effectiveness of entrepreneurship learning by using a Business Incubator has been proven that can be proven by the active participation of students in practice at the Business Incubator at Muhammadiyah 2 Malang Vocational School, and many student activities are carried out in the Business Incubator. Students are also enthusiastic about accepting entrepreneurial learning theory. Teachers also find it easier to explain entrepreneurship learning through practice in the Business Incubator to more easily understand what the teacher has explained about entrepreneurship learning.

Of course, there is entrepreneurship learning in every school, especially in the Marketing, Accounting, and Office Administration majors. Even in other departments, there is entrepreneurship learning. It is not enough if entrepreneurship learning is carried out the only in-class theory. Therefore, schools usually provide a place to practice doing entrepreneurial activities. One of the places to practice entrepreneurship learning owned by Muhammadiyah 2 Malang Vocational School is in the form of a Business Incubator. With the Business Incubator at SMK Muhammadiyah 2 Malang, students can do direct practice according to the teachers' theory.

Many student activities are carried out at the Business Incubator, starting from product arrangement, display arrangement, financial management, purchasing recap, marketing goods to customer service. With the Business Incubator to practice entrepreneurship learning, students can more easily understand and understand entrepreneurship learning, and teachers can easily explain it to students. The existence of a Business Center at SMK Muhammadiyah 2 Malang makes it easier for students to understand entrepreneurship learning. Learning theory in class alone is not enough to broaden students' insights about entrepreneurship, so establishing a Business Incubator as a student practice is very necessary and very helpful in improving learning. On the other hand, the schools here are based on vocational schools where practice must be more than theory.

Barnawi \& Arifin (2012) The purpose of holding entrepreneurship learning, namely (1) building entrepreneurial character; (2) preparing business practice-based entrepreneurship learning services; (3) preparing industrial teaching pilot in SMK; (4) preparing junior high school graduates to become entrepreneurs. In order to achieve this goal, the Business Incubator SMK Muhammadiyah 2 Malang makes programs that involve active students in the management of the program, starting from activities in production, helping to produce original product drinks from SMK Muhammadiyah 2 Malang turmeric Asem, helping packing orders, making products itself for sale. In addition to the production site, students are also actively involved in managing the shop's Business Incubator. In the Business Incubator, students are given picket schedules to be on guard, student activities in the store's Business Incubator, starting from cleaning the room, arranging products, serving customers, recording bookkeeping, etc. by being actively involved in the management of the Business Incubator, it will increase understanding of learning entrepreneurship.

According to Suryono \& Hariyanto (2012), the learning function contains various functions such as helping, guiding, training, nurturing, caring for, growing, encouraging, shaping, straightening, assessing, and developing. The learning functions are carried out by educators, namely teachers, tutors, tutors, coaches, to make changes in themselves according to the learning objectives, which are the goals of education.

The effectiveness of entrepreneurship learning by using a Business Incubator has been proven that can be proven by the active participation of students in practice at the Business Incubator at Muhammadiyah 2 Malang Vocational School. Many student activities are carried out in the Business Incubator. Students are also enthusiastic about accepting entrepreneurial learning theory. Teachers also find it easier to explain entrepreneurship learning through practice in the Business Incubator to more easily understand what the teacher has explained about entrepreneurship learning. 
The effectiveness of the Business Incubator and Entrepreneurial Education in Interest to Start a Business in Vocational School Students Majoring in Marketing

https://doi.org/10.46627/silet.v2i1.61

\section{Empowerment of Business Incubators as a means of fostering interest in opening a business in students}

Apart from being a place to practice entrepreneurship learning and entrepreneurship training, the Business Incubator can help students to provide training on how to trade, how to market an item, and of course, how to open another business. This is done in opening a business by selling goods in the Business Center to be sold in the business environment. It is intended to train students' independence and courage in communicating with customers and the same time learning about entrepreneurship. The Business Incubator aims to improve the skills where students get into the job market. The education delivery system will be successful if supported by good training, an orderly, directed and planned learning process, supported by a supply of educational staff competent in their field of work, and adequate facilities and infrastructure are available (Saptono, 2017). With the Business Incubator SMK Muhammadiyah 2 Malang, it can foster students' characteristics for entrepreneurship.

Suryana (2003) The general characteristics of having an entrepreneurial spirit are full of selfconfidence. The indicators are full of confidence, optimism, commitment, discipline, and responsibility. Having initiative is the indicator that is full of energy, dexterous in action and activity. Have an achievement motivation. The indicator is the possible results and future insight. The indicators are daring to be different and being trustworthy and tough in acting with a leadership spirit. Dare to take calculated risks and therefore love challenges. An entrepreneur is always committed to doing his job to get the expected results. An entrepreneur is not half and half in doing his job because he is always diligent, resilient, never gives up. His actions were not based on speculation but careful calculation. An entrepreneur is brave enough to face risks to his work.

The more courageous they feel the need to show an independent or powerful attitude on behalf of themselves. Likes to imagine and tries to express creativity and introduce the results to other parties. With hard work and accomplished step-by-step progress, self-confidence and a more fundamental attitude of optimism are generated. An entrepreneur always has the principle that what is done is an optimal effort to produce maximum value. This means that entrepreneurs do things carelessly, even though other people can do them. Values and achievements are the things that differentiate between the results of his work as an entrepreneur and others who do not have an entrepreneurial spirit (Alexander \& Honig, 2016; Kalyoncuoğlu et al., 2017; Kouakou et al., 2019; Sherkat \& Chenari, 2020; Walter \& Block, 2016).

Entrepreneurs generally have a higher creative and innovative power than nonentrepreneurs. Things that others have not thought of have already occurred to him, and entrepreneurs can make their innovations into demand. The ideas and behavior of an entrepreneur cannot be separated from the demands and responsibilities. Therefore, commitment is highly treated at work so that it can give birth to responsibility (Kouakou et al., 2019; Ramadani \& Ratten, 2015). Being an entrepreneur, you must always be brave in facing risks. The more students are daring to face the risk, the more excellent the risk, the more excellent the opportunity to take advantage of it, and vice versa (Asimakopoulos et al., 2019; Jabeen et al., 2017, 2017; Kreiser et al., 2010; Pihie \& Arivayagan, 2016; Rapp-Ricciardi et al., 2018). Seeking opportunities does not mean that opportunities already exist. However, entrepreneurs must create their opportunities by creating something new and different and something more valuable, and easy to use.

Students at SMK Muhammadiyah 2 Malang have read business opportunities, especially students majoring in Marketing. In contrast, students majoring in Accounting can read sales finance well. The Business Incubator SMK Muhammadiyah 2 Malang students who previously did not understand buying and selling became. Students who were previously embarrassed in communicating with the Business Incubator practice student were fluent in communicating. Most students desire to become entrepreneurs because by becoming entrepreneurs, students can open jobs for other people, work independently, and work according to their wishes. The benefits of entrepreneurship include the following: Increasing labor capacity, As a generator for 
The effectiveness of the Business Incubator and Entrepreneurial Education in Interest to Start a Business in Vocational School Students Majoring in Marketing

https://doi.org/10.46627/silet.v2i1.61

environmental development, production, distribution, environmental maintenance, welfare, et al. Becoming an example for other members of society, Always respecting applicable laws and regulations, Trying to assist others and social development, according to their abilities, Trying to educate their employees to be independent, disciplined, honest, diligent in dealing with work, Giving an example of how we have to live hard work, but not forgetting religious orders and always getting closer to Allah SWT, Living efficiently does not wasteful and not wasteful, Maintaining environmental harmony.

However, some students do not want to become entrepreneurs because being entrepreneurs requires significant capital, is less respectful, and uncertain. Furthermore, other factors, namely psychological factors that shape society's negative attitude so that they are less interested in the entrepreneurial profession, including aggressive, competitive, selfish, dishonest, stingy, unstable sources of income, less respectful of low jobs, and so on (Descaprio, 2013) The Business Incubator of SMK Muhammadiyah 2 Malang as a means of cultivating students' entrepreneurial characteristics is quite good. This can be seen from students who have an entrepreneurial spirit, have a passion for opening a business, are active in entrepreneurial learning tasks, are honest, tenacious, and creative in practicing entrepreneurship learning in the Business Incubator.

Apart from being a place to practice entrepreneurship learning and entrepreneurship training, the Business Incubator can help students to provide training on how to trade, how to market an item, and of course, how to open another business. This is done in opening a business by selling items in the Business Incubator to be sold in the business environment. Ramadani \& Ratten (2015) It is intended to train students' independence and courage in communicating with customers and at the same time learning about entrepreneurship. Motivation from teachers at school to students needs to be done. Different teachers are also different ways of motivating their students, starting from giving appreciation in the form of cash to students, giving encouragement and praise to students, etc. This is done so that students do not get bored in participating in entrepreneurship learning and can foster students' interest in opening a business.

The existence of entrepreneurship learning and a place to practice entrepreneurship learning in a Business Incubator will indirectly foster students' interest in becoming entrepreneurs. The teachers at SMK Muhammadiyah Malang have stated that the existence of a Business Incubator as support for entrepreneurship learning at SMK Muhammadiyah 2 Malang will increase students' interest in entrepreneurship, on the other hand, the background of the parents of students at SMK Muhammadiyah 2 Malang is an entrepreneur, it makes students want students with the same profession as their parents. Another factor is that it is increasingly difficult to find a job, and the higher the cost of going to college, students want to become entrepreneurs, and it is better to open jobs than to look for jobs. Having been given entrepreneurial skills from the school to students, the teachers at Muhammadiyah 2 Malang Vocational School are sure that their students can become successful entrepreneurs.

In contrast to students whom researchers have interviewed, most students want to be entrepreneurs, and some want to become office employees. Some even want to become office employees as well as entrepreneurs. Based on students' statements, there are different desires, there are those who want to become office employees, bank employees, work in the tax office, the reason is that being entrepreneurs requires significant capital, making products to sell is a complicated process, on the other hand, there are also many students who are interested in becoming entrepreneurs because by becoming entrepreneurs they can opening jobs for other people, can be the boss, not regulated by people, and maybe there is also a family factor, the parents who work as entrepreneurs, finally the child wants to continue the parent's business. Some want to become office employees as well as open businesses.

The Business Incubator of SMK Muhammadiyah 2 Malang as a means of cultivating students' entrepreneurial characteristics is quite good. This can be seen from students who have an entrepreneurial spirit, have a passion for opening a business, are active in entrepreneurial 
The effectiveness of the Business Incubator and Entrepreneurial Education in Interest to Start a Business in Vocational School Students Majoring in Marketing

https://doi.org/10.46627/silet.v2i1.61

learning tasks, are honest, tenacious, and creative in practicing entrepreneurship learning in the Business Incubator.

\section{CONCLUSION}

Based on the discussion, the researcher can draw the following conclusions.

Management of the Business Incubator at SMK Muhammadiyah 2 Malang has 3 parts. The first part is a photocoppy room, used for student practice activities majoring in Office Administration and Islamic Banking, the second part is the production room, is used for practical activities majoring in Marketing, the third is the Entrepreneurship room, mainly used for students majoring in Marketing, but students majoring in Office Administration, Accounting, Sharia banking is also actively involved in managing the entrepreneurial space Business Incubator. The facilities and infrastructure contained in the Business Incubator of Muhammadiyah 2 Malang Vocational School, according to the researcher, were insufficient, it caused students to change their practice places in the entrepreneurial space Business Incubator. Meanwhile, in the Business Incubator in the Production room, little equipment is used. The entrepreneurial space business incubator is good enough. With the Business Incubator at SMK Muhammadiyah 2 Malang, entrepreneurship learning is very effective, teachers can easily explain entrepreneurship theory to students, while students can quickly understand what is explained by the teacher so that it can improve entrepreneurship learning. Empowering the Business Incubator as a means of fostering student interest in opening a business has gone well. With the existence of entrepreneurship learning and the Business Incubator as a place for practice, students understand entrepreneurship and can foster students' interest in opening a business.

The limitation in this research is regarding the problem of financial management and distribution of sales results, for further researchers it can be suggested to further develop digitalbased business incubators and digital entrepreneurship learning.

\section{REFERENCES}

Alexander, I. K., \& Honig, B. (2016). Entrepreneurial Intentions: A Cultural Perspective. Africa Journal of Management, 2(3), 235-257. https://doi.org/10.1080/23322373.2016.1206801

Amin, P., Arini, D., \& Permadi, W. (2020). Memetakan Bakat Dan Minat SIswa Dengan Membangun Mental Wirausaha Guna Mendukung Program Ekonomi Kreatif Di Lingkungan Sekolah. Jurnal Masyarakat Mandiri, 4(2), 308-318. http://garuda.ristekbrin.go.id/documents/detail/1726238

Asimakopoulos, G., Hernández, V., \& Miguel, J. P. (2019). Entrepreneurial intention of engineering students: The role of social norms and entrepreneurial self-efficacy. Sustainability (Switzerland), 11(16), 1-17. https://doi.org/10.3390/su11164314

Barnawi, \& Arifin, M. (2012). School Preneurship Membangkitkan Jiwa \& Sikap Kewirausahaan Siswa. Arruzmedia.

Basri, I. Y., Faiza, D., Nasir, M., \& Nasrun, N. (2019). Implementasi Pembelajaran Berbasis Produk Dalam Rangka Menyiapkan Lulusan SMK Menjadi Wirausahawan Muda. INVOTEK: Jurnal Inovasi Vokasional Dan Teknologi, 19(1), 43-52. https://doi.org/10.24036/invotek.v19i1.433

Budiyanto, H., Suprapto, A., \& Poerwoningsih, D. (2017). Program Pengembangan Kewirausahaan Dalam Bentuk Inkubator Bisnis Di Perguruan Tinggi Bagi Mahasiswa Pemilik Usaha Pemula. Seminar Nasional Sistem Informasi (Senasif) 2017, September, 385-394. https:// seminar.unmer.ac.id/index.php/senasif/2017/paper/view/33/39

Descaprio. (2013). Tips Mengelola Laboratorium Sekolah. Diva press.

Emha. (2006). Pedoman Penggunaan Laboratorium Sekolah. Rosdakarya.

Jabeen, F., Faisal, M. N., \& Katsioloudes, M. I. (2017). Entrepreneurial mindset and the role of universities as strategic drivers of entrepreneurship: Evidence from the United Arab Emirates. Journal of Small Business and Enterprise Development, 24(1), 136-157. https:// doi.org/10.1108/JSBED-07-2016-0117 
The effectiveness of the Business Incubator and Entrepreneurial Education in Interest to Start a Business in Vocational School Students Majoring in Marketing

https://doi.org/10.46627/silet.v2i1.61

Kalyoncuoğlu, S., Aydıntan, B., \& Göksel, A. (2017). The Effect of Entrepreneurship Education on Entrepreneurial Intention: An Experimental Study on Undergraduate Business Students. Journal of Management Research, 9(3), 72. https:/ / doi.org/10.5296/jmr.v9i3.11282

Komara, B. D., \& Setiawan, H. C. B. (2020). Inkubator Bisnis Sebagai Pendorong Tumbuhnya Wirausaha Muda: Studi Tentang Suksesi Kewirausahaan Mahasiswa Universitas Muhammadiyah Gresik. Jurnal Riset Entrepreneurship, 3(1), 33. https:// doi.org/10.30587/jre.v3i1.1159

Kouakou, K. K. E., Li, C., Akolgo, I. G., \& Tchamekwen, A. M. (2019). Evolution View of Entrepreneurial Mindset Theory. International Journal of Business and Social Science, 10(6). https:// doi.org/10.30845/ijbss.v10n6p13

Lutfiani, N., Rahardja, U., \& Manik, I. S. P. (2020). Peran Inkubator Bisnis dalam Membangun Startup pada Perguruan Tinggi. Jurnal Penelitan Ekonomi Dan Bisnis, 5(1), 77-89. https:// doi.org/10.33633/jpeb.v5i1.2727

Moslem, M. C., Komaro, M., \& Indonesia, U. P. (2019). Faktor-Faktor Yang Menyebabkan Rendahnya Motivasi Belajar Siswa Dalam Mata Pelajaran Aircraft Drawing Di Smk. Journal of Mechanical Engineering Education, 6(2), 258-265. https:// doi.org/10.17509/jmee.v6i2.21803

Nastiti, F. El., \& 'Abdu, A. R. N. (2020). Kesiapan Pendidikan Indonesia Menghadapi era society 5.0. Jurnal Kajian Teknilogi Pendidikan, 5(1), 61-66.

Perwita, D. (2017). Upaya Guru Sekolah Menengah Kejuruan (SMK) Dalam Meningkatkan Minat Berwirausaha Siswa. Jurnal Pendidikan Ekonomi UM Metrro, 5(2), 9-14. http://ojs.fkip.ummetro.ac.id/index.php/ekonomi/article/view/1209

Pihie, L., \& Arivayagan, K. (2016). Predictors of Entrepreneurial Mindset among University Students. International Journal of Humanities, Social Sciences and Education, 3(7), 1-9. https:/ / doi.org/10.20431/2349-0381.0307001

Prihastiwi, D. A., Army, Y., \& ... (2018). Optimalisasi Peran SMK sebagai Pencetak Wirausahawan Muda melalui Penguatan Motivasi dan Pembekalan Keterampilan dan Pengetahuan .... ... Seminar Nasional Unimus, 1, 374-380. http:// prosiding.unimus.ac.id/index.php/semnas/article/download/63/61

Ramadani, V., \& Ratten, V. (2015). The context of Islamic entrepreneurship and business : Concept , principles and perspectives The context of Islamic entrepreneurship and business : concept , principles and perspectives Veland Ramadani * Léo-Paul Dana Vanessa Ratten Sadush Tahiri. International Journal of Business and Globalisation, 15(January), 244-261. https:// doi.org/10.1504/IJBG.2015.071906

Rami, T. P., \& Supardi, E. (2019). Kreativitas Mengajar Guru Berkontribusi Terhadap Minat Belajar Siswa Pada Mata Pelajaran Kewirausahaan. Jurnal Pendidikan Manajemen Perkantoran, 4(2), 254. https:// doi.org/10.17509/jpm.v4i2.18021

Rapp-Ricciardi, M., Widh, J., Barbieri, B., Amato, C., \& Archer, T. (2018). Dark triad, locus of control and affective status among individuals with an entrepreneurial intent. Journal of Entrepreneurship Education, 21(1), 1-18.

Rifai, I. A., \& Sucihatiningsih, D. W. . (2016). Pengaruh Pendidikan Kewirausahaan Dan Pelaksanaan Kegiatan Business Center Terhadap Minat Berwirausaha Siswa Kelas Xi Jurusan Pemasaran Smk Negeri 2 Semarang Tahun Ajaran 2015/2016. Journal of Economic Education, 5(1), 39-51. http://journal.unnes.ac.id/sju/index.php/jeec

Sabatari, W., \& Hariyanto, V. L. (2015). Upaya Pembelajaran Kewirausahaan Di Smk Potret Komitmen Terhadap Standar Nasional Proses Pendidikan Dan Pembelajaran. Jurnal $\begin{array}{lllll}\text { Pendidikan Teknologi Dan Kejuruan UNY, 21(3), } 164048 . & \end{array}$ https:// doi.org/10.21831/jptk.v21i3.3259

Saptono, A. (2017). Menumbuhkan Intensi Berwirausaha Siswa Smk Melalui Inkubasi Bisnis. Prosiding Seminar Pendidikan Ekonomi Dan Bisnis, 3(1). http://jurnal.fkip.uns.ac.id/index.php/snpe/article/download/10675/8352\%0Ahttp://j 
urnal.fkip.uns.ac.id/index.php/snpe/article/view/10675/8352\%0Ahttps:/ / lens.org/087006-885-995-82X

Sherkat, A., \& Chenari, A. (2020). Assessing the effectiveness of entrepreneurship education in the universities of Tehran province based on an entrepreneurial intention model. Studies in Higher Education, 0(0), 1-19. https:/ / doi.org/10.1080/03075079.2020.1732906

Suherman. (2010). Desain Pembelajaran Kewirausahaan. Kencana.

Susanto, I. (2017). Korelasi Kemampuan Pengelolaan Laboratorium. Jurnal Penelitian Bidang Pendidikan, 23(2), 80-85.

Ulgari, S., Aritonang, A. Z., \& Manulang, R. (2020). Hubungan Kemampuan Menerapkan Teknik Pembuatan dan Disiplin Belajar SIswwa dengan Minat Berwirausaha. Journal of Mechanical Engineering Learning, 9(2).

Usman, H., \& Raharjo, N. E. (2012). Model Pendidikan Karakter Kewirausahaan Di Sekolah Menengah Kejuruan. Jurnal Pendidikan Teknologi Dan Kejuruan UNY, 21(2), 163617. https:// doi.org/10.21831/jptk.v21i2.2940

Walter, S. G., \& Block, J. H. (2016). Outcomes of entrepreneurship education: An institutional perspective. Journal of Business Venturing, 31(2), 216-233. https:// doi.org/10.1016/j.jbusvent.2015.10.003

Wibowo, A. (2017). Dampak Pendidikan Kewirausahaan bagi Mahasiswa. Asian Journal of Entrepreneurship and Family Business, 01(01), 1-14. https:/ / doi.org/10.21632/ajefb.1.1.1-14

\section{Author (s):}

Raya Sulistyowati

Department of Economics Educations, Faculty of Economic and Business

Universitas Negeri Surabaya,

Jl. Ketintang, Surabaya 60231, Indonesia

Email: rayasulistyowati@unesa.ac.id 